\title{
Water saving under fixed-furrow surface irrigation in clay soil of the Middle Nile Delta of Egypt
}

\author{
A. A. Abd El-Halim \\ Soil and Water Department, Faculty of Agriculture, \\ Tanta University, Egypt
}

\begin{abstract}
Fixed-furrow irrigation $\left(\mathrm{FFI}_{14}\right.$ with 14 days interval and $\mathrm{FFI}_{7}$ with seven day interval) were used to investigate the impacts of deficit irrigation on maize yield, maize-water relations and economic return for the Middle Nile Delta soils compared with conventional every furrow irrigation method with 14 days interval (EFI). The results indicated that grain yield was increased with $\mathrm{FFI}_{7}$, whereas it tended to decrease under $\mathrm{FFI}_{14}$, in comparison to EFI. The water applied is reduced with $\mathrm{FFI}_{7}$ and $\mathrm{FFI}_{14}$ when compared to EFI. The crop water use decreased under the $\mathrm{FFI}_{7}$ and $\mathrm{FFI}_{14}$ techniques as compared to EFI. The $\mathrm{FFI}_{7}$ scheme exhibited improved crop water use efficiency values, compared to EFI. The results indicated also that $\mathrm{FFI}_{7}$ treatment does not only increase grain yield, benefit-cost ratio and net return, but also save irrigation water.

Keywords: maize, Zea mays L., fixed-furrow irrigation, maize-water relations, benefit-cost ratio (BCR).
\end{abstract}

\section{Introduction}

Water resources in Egypt are limited, which restrict crop production in the newly reclaimed lands because of the present intensive agricultural production in the Nile Delta and valley area and agriculture in Egypt relies heavily on irrigation. The agricultural sector consumes more than $84 \%$ of the available water resources (ElBeltagy and Abo-Hadeed [1]).

Maize is one of the major cereal crops in Egypt. It is the most important foodstuff, which provides the daily bread for the indigenous population of rural areas. Thus, it can be considered as the second feed crop after wheat. Maize 
production in Egypt is about 12 million tons of grain (USDA [2]). Improving maize production with saving irrigation water and maximizing profits, could be achieved by determining water-yield relationships and choose the most appropriate irrigation method.

The common irrigation method used for maize production in the Middle Nile Delta of Egypt is surface furrow irrigation. Such irrigation scheme characterized by low application efficiency (45-60\%) and causes significant water losses, mainly due to excess deep percolation from the irrigated fields (Mitchell et al. [3] and Raine and Bakker [4]). Accordingly, irrigation methods require fundamental changes in water management in order to use the limited water resources efficiently.

Deficit irrigation has been used as a water saving method in agricultural production to increase benefit and water use efficiency as mentioned by Mitchell et al. [5] and Behboudian and Mills [6]. Deficit irrigation, under furrow irrigation, can be induced via different irrigation techniques such as fixed-furrow. Fixedfurrow irrigation is a way to save water and showed a small improvement over the alternate furrow irrigation (Slatni et al. [7]). Fixed-furrow irrigation is a preferable irrigation water management in areas with a scarce amount of irrigation water and rainfall (Sepaskhah and Hosseini [8]). In this regard, every-other furrow irrigation saved water and increased maize yield (Shayannejad and Moharrery [9] and Rafiee and Shakarami [10]).

The economical and environmental benefit of using every-other furrow irrigation method is higher than any other irrigation methods, because less water is applied and a greater economic return can be obtained (Nelson and Al-Kaisi [11]).

The objective of this research is to study the effects of deficit irrigation, via fixed-furrow (FFI) irrigation technique with two different schemes compared with the every furrow irrigation (EFI) technique on maize yield, water relations, and economic returns.

\section{Materials and methods}

\subsection{Description of the studied area}

The field experiment was conducted at a private farm, lies $15 \mathrm{~km}$ north to Tanta city, Al-Gharbiya governorate during the 2010 and 2011 seasons. The soil of the studied area is characterized by a clay texture with water table deeper than three meters. Hydro-physical characteristics of the soil at the experimental field are determined as outlined by Ryan et al. [12] and shown in Table 1.

\subsection{Treatments and experimental design}

The irrigation treatments were:

1) Every-furrow irrigation (conventional irrigation method, EFI), in which irrigation was applied at 14-day intervals after Mohyah irrigation. 
Table 1: Hydro-physical characteristics of the soil of the experimental field.

\begin{tabular}{|l|ccc|ccc|}
\hline \multirow{3}{*}{ Characteristics } & \multicolumn{4}{|c|}{2010} & \multicolumn{3}{|c|}{2011} \\
\cline { 2 - 7 } & \multicolumn{6}{|c|}{ Soil depth, cm } \\
\cline { 2 - 7 } & $0-30$ & $30-60$ & $60-90$ & $0-30$ & $30-60$ & $60-90$ \\
\hline Sand (\%) & 24.36 & 21.86 & 25.10 & 22.90 & 19.60 & 23.10 \\
Silt (\%) & 26.58 & 27.75 & 40.10 & 31.88 & 32.25 & 40.20 \\
Clay (\%) & 49.06 & 50.39 & 34.80 & 47.22 & 48.15 & 36.70 \\
Soil texture & Clay & Clay & Clay Loam & Clay & Clay & Clay Loam \\
Bulk density $\left(\mathrm{g} \mathrm{cm}^{-3}\right)$ & 1.26 & 1.40 & 1.49 & 1.24 & 1.38 & 1.47 \\
FC $^{\text {a }}\left(\%, w^{-1}\right)$ & 41.60 & 38.60 & 38.20 & 41.30 & 38.60 & 38.00 \\
PWP $^{\text {b }}\left(\%, w^{-1}\right)$ & 21.78 & 20.84 & 20.51 & 21.81 & 20.54 & 20.10 \\
AW $^{\text {c }}\left(\mathrm{mm} \mathrm{depth}^{-1}\right)$ & 74.92 & 74.59 & 79.07 & 72.50 & 74.77 & 78.94 \\
\hline
\end{tabular}

Note: FC is moisture content at field capacity; PWP is moisture content at wilting point; AW is available water content.

2) Fixed every other furrow irrigation $\left(\mathrm{FFI}_{7}\right)$ in which irrigation was fixed to one of the two neighboring furrows and watering was applied at 7-day intervals, i.e. during the growing season irrigating one furrow and kept the other adjacent one without watering.

3) Fixed every other furrow irrigation $\left(\mathrm{FFI}_{14}\right)$ which was similar to $\mathrm{AFI}_{7}$, but watering was applied at 14-day intervals.

The experimental plot size is $45.5 \mathrm{~m}^{2}$ (9.1 $\mathrm{m}$ width $\times 5 \mathrm{~m}$ length). Each treatment included 15 furrows and 14 planting ridges (rows), spaced $0.65 \mathrm{~m}$ apart. The experimental plots were separated by earthen banks $(1.3 \mathrm{~m}$ wide and $0.5 \mathrm{~m}$ high) to reduce the lateral movement of irrigation water.

\subsection{Agronomic practices}

Maize (Zea mays L.) seeds (TWC 324) were sown at $36 \mathrm{~kg} \mathrm{ha}^{-1}$ seeding rate in May 25 in the two growing seasons. All agronomic practices e.g. plant density, Nfertilization weed and insect control, etc. were kept normal and performed at the appropriate time. The experimental treatments were imposed after the second pretreatment irrigation in both seasons. Maize was harvested at 123 days after planting (DAP) by cutting the aboveground biomass, and left for further drying before removing the cobs from the stalks. Then, grains were threshed and the grain yield (at 15\% moisture content) was measured.

\subsection{Irrigation management}

A polyvinyl chloride pipe of $15 \mathrm{~cm}$ internal diameter and $40 \mathrm{~cm}$ length was used to convey the water into each plot. This pipe was installed to give a free water flow. The discharge was calculated according to the following formula:

$$
\mathrm{Q}=\mathrm{CA} \sqrt{2 \mathrm{gh}}
$$


where $\mathrm{Q}$ is the discharge rate $\left(\mathrm{cm}^{3} \mathrm{sec}^{-1}\right) ; \mathrm{C}$ is the discharge coefficient of the orifice $(0.61)$; $\mathrm{g}$ is the acceleration of gravity $\left(\mathrm{cm} \mathrm{sec}^{-2}\right)$; $\mathrm{A}$ is the orifice cross sectional area $\left(\mathrm{cm}^{2}\right)$ and $\mathrm{h}$ is the effective water head above the orifice center. The effective water head was measured several times during the pre-treatment irrigation, estimated to be $8.3 \mathrm{~cm}$, and was used to calculate the discharge of the pipes in this study. At the time of irrigation, water enters the plot through the pipe till it fills the furrows as the local farmers irrigating their fields, and the time is recorded using a stopwatch. Furrows, which are subjected to irrigation, are open ended, whereas the others which are not subjected to irrigation are close ended or diked. The pipe discharge and the duration of the irrigation determine the total amount of applied water, which should match the crop water requirement in the ideal situation. The depth of the applied water was calculated using the following formula:

$$
\mathrm{d}=\mathrm{Qt} \times 1000 / \mathrm{A}
$$

where $\mathrm{d}$ is the depth $(\mathrm{mm})$; $\mathrm{Q}$ is the discharge $\left(\mathrm{m}^{3} \mathrm{~min}^{-1}\right)$; $\mathrm{t}$ is the time (min) and A is the plot area $\left(\mathrm{m}^{2}\right)$. Total applied irrigation water (AIW) was calculated by summing the amounts of water added at each irrigation event during the entire growing season.

\subsection{Maize-water relation parameters}

Soil samples were taken by a screw auger at planting, before and two days after each irrigation event, and at harvest. Samples were taken on the beds and in the furrows at three depths: 0-30, 30-60 and 60-90 cm. In fixed-furrow irrigation treatments, the soil samples were taken for both the irrigated and dry furrows. The samples were used to measure the volumetric soil-water content in the root zone using the gravimetric method, based on the conventional oven-dry weight, and multiplied by the bulk density. Then next parameters were calculated.

\subsubsection{Crop water use (CWU)}

Crop water use (CWU) was calculated based on the soil moisture depletion (Michael [13]) as follows:

$$
\mathrm{CWU}=\sum_{\mathrm{i}=1}^{\mathrm{n}}\left(\mathrm{VMC}_{1 \mathrm{i}}-\mathrm{VMC}_{2 \mathrm{i}}\right) \times \mathrm{D}_{\mathrm{i}}
$$

where $\mathrm{CWU}$ is the crop water use $(\mathrm{mm}) ; \mathrm{VMC}_{1 \mathrm{i}}$ is the volumetric moisture content at the time of the first sampling in the $\mathrm{i}^{\text {th }}$ layer; $\mathrm{VMC}_{2 \mathrm{i}}$ is the volumetric moisture content at the time of the second sampling in the $\mathrm{i}^{\text {th }}$ layer; $\mathrm{D}$ is the depth of the $\mathrm{i}^{\text {th }}$ layer of the soil (mm); and $\mathrm{n}$ is the number of soil layers. Total crop water use was obtained as a summation of CWU for each irrigation cycle.

\subsubsection{Crop water use efficiency (CWUE)}

Crop water use efficiency (CWUE) or so-called in other references crop water productivity (CWP) was computed by dividing the maize yield on crop water use. 
Irrigation water use efficiency (IWUE) or so-called in other references irrigation water productivity (IWP) was determined as the ratio of maize yield to the applied irrigation water for a particular treatment (Howell et al. [14]), according to the following equations.

$$
\begin{gathered}
\mathrm{CWUE}=\mathrm{Y} / \mathrm{CWU} \\
\mathrm{IWUE}=\mathrm{Y} / \mathrm{Wa}
\end{gathered}
$$

where $\mathrm{Y}$ is the grain yield $\left(\mathrm{kg} \mathrm{ha}^{-1}\right)$; CWU is the crop water use $\left(\mathrm{m}^{3} \mathrm{ha}^{-1}\right)$ and $\mathrm{Wa}$ is the applied water $\left(\mathrm{m}^{3} \mathrm{ha}^{-1}\right)$.

\subsection{Benefit-cost ratio (BCR) and net return (NR)}

The farming cost includes mainly the operation and variable costs. The operating cost (labor, land preparation, seeds, fertilizers, and chemicals) were based on the planted area. Therefore, the operating costs of the two fixed-furrow irrigation treatments were the same as the conventional every furrow irrigation treatment and it was 2500 Egyptian pounds (LE) per hectare (exchange rate: $1 \mathrm{LE} \approx$ 0.17 US\$; rate, in 2011). The variable costs depended on the number of irrigations and price per unit of water. The indigenous irrigation farmers in the studied area do not pay for water used in their farms. Therefore, they bear only the costs of labor used in irrigation (estimated $250 \mathrm{LE} \mathrm{ha}^{-1}$ based on the irrigated area and the man-day labor cost of $50 \mathrm{LE}$ ), as well as the price of fuel used to run a pump to withdraw water from irrigation canals. The price of water unit was estimated to be $0.25 \mathrm{LE} \mathrm{m}^{-3}$. The total cost of water for each season was calculated by multiplying the price of water unit in total quantity of irrigation water required for the maize crop. The gross revenue has been calculated by multiplying the total yield in kilogram per hectare and market price of maize per kilogram. In this study the farm-gate price for maize grain was $1.6 \mathrm{LE} \mathrm{kg}^{-1}$ (a locally price). The net profits and benefit-cost ratio (BCR) due to irrigation were calculated according to Sampath and Nobe [15] and Li et al. [16] as follows:

$$
\begin{aligned}
\text { Net profits } & =\text { Gross revenue }- \text { Farming costs } \\
\mathrm{BCR} & =\text { Net profits } / \text { Farming costs }
\end{aligned}
$$

The net return (NR) from the irrigation treatment that lead to increase the grain yield was calculated by summing the cost of saved water and the revenue increase due to increase yield. On the other hand, the NR from the irrigation treatment that lead to decrease the grain yield was calculated as the difference between the costs of water saved and the revenue lost due to yield decrease. This was expressed as:

$$
\mathrm{NR}=(\mathrm{c} \times \mathrm{WS}) \pm(\mathrm{p} \times \mathrm{YL})
$$

where WS is the volume of water saved per hectare; YL is the yield increase or decrease per hectare; $c$ is the unit price per $\mathrm{m}^{3}$ of water; and $\mathrm{p}$ is the unit price per $\mathrm{kg}$ of grain yield. 


\subsection{Statistical analysis}

Statistical ANOVA was performed with MSTATC ${ }^{\mathrm{TM}}$ version 2.0. The significant differences between means were tested using Duncan's Multiple Range Test (DMRT) at significantly level of $5 \%$.

\section{Results and discussions}

Grain yield was significantly affected by irrigation treatments (Table 2). Results showed that the yield under $\mathrm{FFI}_{7}$ and EFI treatments were higher than that obtained from $\mathrm{FFI}_{14}$, which reached 8.40 and $8.12 \mathrm{t} \mathrm{ha}^{-1}$ (average over the two seasons), respectively. The grain yield as an average over the two seasons under the $\mathrm{FFI}_{7}$ treatment increased by $0.28 \mathrm{t} \mathrm{ha}^{-1}$, whereas $\mathrm{FFI}_{14}$ decreased the yield by $1.64 \mathrm{t} \mathrm{ha}^{-1}$ in comparison to the EFI. This might be due to the less amount of applied irrigation water under $\mathrm{FFI}_{14}$, which did not match full maize water requirements. This caused water stress and consequently reduced crop yield. This result is in parallel with those reported by Rafiee and Shakarami [10]. However, The $\mathrm{FFI}_{14}$ treatment was more water saving $(76 \mathrm{~mm})$ than the $\mathrm{AFI}_{7}(47 \mathrm{~mm})$ as an average over the two seasons. In general, more frequent irrigation interval ( 7 day) in fixed-furrow resulted in higher grain yield than less frequent irrigation interval (14 day). Ibrahim and Kandil [17] reported the same results. Moreover, Sepaskhah and Ghasemi [18] found that more frequent irrigation (10-days interval) with higher air evaporation potential resulted in higher application of irrigation water and grain and top yields of grain sorghum.

Applied irrigation water (AIW) was significantly affected by irrigation treatments (Table 2). The results of 2-year average (Table 2) showed that AIW under the $\mathrm{FFI}_{7}(1017 \mathrm{~mm})$ was not equal to that applied under EFI $(1063 \mathrm{~mm})$; however, grain yield increased $\left(0.28 \mathrm{t} \mathrm{ha}^{-1}\right)$. On the other hand, not acceptable grain yield decrease (1.64 tha-1) was observed with less amount of IWA (988 mm) under $\mathrm{FFI}_{14}$ treatment in comparison to conventional irrigation (EFI). The small amount of $\mathrm{AIW}$ with the $\mathrm{FFI}_{14}$ and $\mathrm{AFI}_{7}$ treatments compared to the EFI, could be attributed to the nature of the two treatments, which they supply water in a manner that greatly reduces the amount of surface wetted, leading to less evapotranspiration and less deep percolation. On the other hand, the amount of AIW was more with fixed-furrow irrigation at 7-day intervals than at 14-day intervals. This can be attributed to more frequent irrigation, which resulted in higher evaporation from the soil surface, and high available soil moisture, which subjected to more absorption and consequently increased transpiration, especially during the early part of the growing season with incomplete ground cover. In addition, less crop water use efficiency and irrigation water uses efficiency under fixed-furrow irrigation at 14-day interval scheme.

Crop water use (CWU) was significantly affected by irrigation treatments (Table 2). The results of 2-year average (Table 2) showed that the highest CWU $(829 \mathrm{~mm})$ was recorded under EFI. This is followed by $799 \mathrm{~mm}$ under FFI. The lowest value $\left(762 \mathrm{~mm}\right.$ ) was obtained under $\mathrm{FFI}_{14}$ treatment. The CWU under EFI 
Table 2: Applied irrigation water, crop water use, crop water use efficiency and irrigation water use efficiency under different irrigation treatments.

\begin{tabular}{|c|c|c|c|c|}
\hline \multirow{2}{*}{ Property } & \multirow{2}{*}{ Treat. } & \multicolumn{2}{|c|}{ Season } & \multirow{2}{*}{ Avg. } \\
\hline & & 2010 & 2011 & \\
\hline \multirow{3}{*}{ Grain yield $\left(\mathrm{t} \mathrm{ha}^{-1}\right)$} & EFI & $7.84^{\mathrm{a}}$ & $8.40^{\mathrm{a}}$ & $8.12^{b}$ \\
\hline & $\mathrm{FFI}_{7}$ & $8.10^{\mathrm{a}}$ & $8.70^{\mathrm{a}}$ & $8.40^{\mathrm{a}}$ \\
\hline & $\mathrm{FFI}_{14}$ & $6.50^{\mathrm{b}}$ & $6.80^{\mathrm{b}}$ & $6.70^{\mathrm{c}}$ \\
\hline \multirow{3}{*}{ Yield increase $(+)$ or loss $(-)\left(\mathrm{t} \mathrm{ha}^{-1}\right)$} & EFI & - & - & - \\
\hline & $\mathrm{FFI}_{7}$ & 0.26 & 0.30 & 0.28 \\
\hline & $\mathrm{FFI}_{14}$ & -1.64 & -1.60 & -1.62 \\
\hline \multirow{3}{*}{ Applied irrigation water (mm) } & EFI & $1058^{a}$ & $1068^{a}$ & $1063^{\mathrm{a}}$ \\
\hline & $\mathrm{FFI}_{7}$ & $1010^{\mathrm{b}}$ & $1023^{b}$ & $1017^{\mathrm{b}}$ \\
\hline & $\mathrm{FFI}_{14}$ & $985^{\mathrm{c}}$ & $990^{c}$ & $988^{c}$ \\
\hline \multirow{3}{*}{ Water saving $(\mathrm{mm})$} & EFI & - & - & - \\
\hline & $\mathrm{FFI}_{7}$ & 48 & 45 & 47 \\
\hline & $\mathrm{FFI}_{14}$ & 73 & 78 & 76 \\
\hline \multirow{3}{*}{ Crop water use (mm) } & EFI & $825^{\mathrm{a}}$ & $833^{\mathrm{a}}$ & $829^{\mathrm{a}}$ \\
\hline & $\mathrm{FFI}_{7}$ & $795^{\mathrm{b}}$ & $803^{\mathrm{b}}$ & $799^{\mathrm{b}}$ \\
\hline & $\mathrm{FFI}_{14}$ & $752^{\mathrm{c}}$ & $772^{c}$ & $762^{c}$ \\
\hline \multirow{3}{*}{ Crop water use efficiency $\left(\mathrm{kg} \mathrm{m}^{-3}\right)$} & EFI & $0.95^{b}$ & $1.01^{\mathrm{b}}$ & $0.98^{b}$ \\
\hline & $\mathrm{FFI}_{7}$ & $1.02^{\mathrm{a}}$ & $1.08^{\mathrm{a}}$ & $1.05^{\mathrm{a}}$ \\
\hline & $\mathrm{FFI}_{14}$ & $0.86^{\mathrm{c}}$ & $0.88^{\mathrm{c}}$ & $0.87^{\mathrm{c}}$ \\
\hline \multirow{3}{*}{ Irrigation water use efficiency $\left(\mathrm{kg} \mathrm{m}^{-3}\right)$} & EFI & $0.74^{\mathrm{b}}$ & $0.79^{\mathrm{b}}$ & $0.77^{b}$ \\
\hline & $\mathrm{FFI}_{7}$ & $0.80^{\mathrm{a}}$ & $1.08^{\mathrm{a}}$ & $0.94^{\mathrm{a}}$ \\
\hline & $\mathrm{FFI}_{14}$ & $0.66^{\mathrm{c}}$ & $0.69^{c}$ & $0.68^{c}$ \\
\hline
\end{tabular}

Note: $\mathrm{EFI}, \mathrm{AFI}_{7}$, and $\mathrm{FFI}_{14}$ are referred to Every Furrow Irrigation, Fixed-Furrow Irrigation with 7-day intervals, and Fixed-Furrow Irrigation with 14-day intervals, respectively; Avg. is referred to average over the two seasons; Means column under each subheading followed by different letter $(a, b, c)$ are significantly different from each other at $\mathrm{P} \leq 0.001$.

and $\mathrm{FFI}_{7}$ was higher than the $\mathrm{FFI}_{14}$ treatment, which could be attributed to the sufficient soil moisture in the effective root zone with the EFI and $\mathrm{FFI}_{7}$ treatment, which received regular watering during the growing season. The lowest CWU observed under the $\mathrm{FFI}_{14}$, may be due to that maize plant, grown under the condition of the $\mathrm{FFI}_{14}$ treatment were subjected to moisture stress resulted from less frequent irrigation and less quantity of applied water according to the nature of such technique.

On the other hand, crop water use efficiency (CWUE) and irrigation water use efficiency (IWUE) are significantly affected by irrigation treatments (Table 2). Results from the 2-year average indicated that the highest CWUE value $\left(1.05 \mathrm{~kg} \mathrm{~m}^{-3}\right)$ was recorded with $\mathrm{FFI}_{7}$ treatment, followed by 0.98 and $0.87 \mathrm{~kg} \mathrm{~m}^{-3}$ with EFI and $\mathrm{FFI}_{14}$, respectively. Also, the highest IWCU obtained with $\mathrm{FFI}_{7}$ is 
$0.94 \mathrm{~kg} \mathrm{~m}^{-3}$, followed by $0.77 \mathrm{~kg} \mathrm{~m}^{-3}$ obtained with EFI treatment, while the lowest irrigation water use efficiency (IWUE) reached $0.68 \mathrm{~kg} \mathrm{~m}^{-3}$ under $\mathrm{FFI}_{14}$ treatment. These results indicated that fixed-furrow irrigation at 7-days interval is appropriate method to increase CWUE and IWUE, because it allows applying less irrigation water, under the present trial. This finding confirms the finding of Slatni et al. [7] who conducted a field experiment to evaluate three irrigation techniques e.g. AFI, FFI and CFI for a potato crop. The author added that application and irrigation efficiency were the highest in FFI and lowest in CFI. The CWUE obtained from various irrigation treatments confirm the potency of deficit irrigation in enhancing the CWUE criterion. The high CWUE value obtained with fixed-furrow irrigation at 7-days interval compared to EFI could be due to the high yield obtained with this treatment. The IWUE offers a clear picture of the effectiveness of irrigation water applied. In general, the IWUE was high with the fixed-furrow irrigation at 7-days interval. This could be due to less amount of applied water compared to EFI treatment.

The maximum BCR was 1.80 and 1.61 obtained from $\mathrm{FFI}_{7}$, followed by 1.60 and 1.44 from EFI, whereas the minimum was 1.07 and 1.15 observed with $\mathrm{FFI}_{14}$ in the $1^{\text {st }}$ and $2^{\text {nd }}$ seasons, respectively (Table 3 ). The maximum NR were 625 and $598 \mathrm{LE} \mathrm{ha}^{-1}$ as obtained from $\mathrm{FFI}_{7}$, compared to the EFI, in the $1^{\text {st }}$ and $2^{\text {nd }}$ seasons, respectively. The other treatment $\mathrm{FFI}_{14}$ did not achieve any NR in both seasons (Table 3). Khan et al. [19] reported that the economic importance of the used water could be worked out for specific situation prior to the large-scale adoption for commercial plant production. However, the use of irrigation intervals for better growth and higher yield could be economically attractive to reduce the drought stressed conditions in water limiting areas. Among different irrigation treatments, fixed-furrow irrigation with 7-days interval $\left(\mathrm{FFI}_{7}\right)$ resulted in the maximum return and the highest BCR in both seasons of study. These results could be due to developing and improving CWUE with the $\mathrm{FFI}_{7}$, which leads to high yield.

Table 3: Benefit-cost ratio (BCR) and net return (NR) associated with the adopted irrigation treatments.

\begin{tabular}{|cccccccc|}
\hline Treat. & Season & $\begin{array}{c}\text { Cost of water } \\
\text { applied } \\
\text { LE ha }\end{array}$ & $\begin{array}{c}\text { Farming } \\
\text { cost } \\
\text { LE ha }^{-1}\end{array}$ & $\begin{array}{c}\text { Gross } \\
\text { revenue } \\
\text { LE ha }^{-1}\end{array}$ & $\begin{array}{c}\text { Net } \\
\text { profit } \\
\text { LE ha }^{-1}\end{array}$ & (BCR) & $\begin{array}{c}\text { (NR) } \\
\text { ha }\end{array}$ \\
\hline \multirow{2}{*}{ EFI } & 2010 & 2645 & 5145 & 12544 & 7399 & 1.44 & - \\
& 2011 & 2670 & 5170 & 13440 & 8270 & 1.60 & - \\
\hline \multirow{2}{*}{ FFI $_{7}$} & 2010 & 2463 & 4963 & 12960 & 7997 & 1.61 & 598 \\
& 2011 & 2475 & 4975 & 13920 & 8945 & 1.80 & 625 \\
\hline \multirow{2}{*}{ FFI $_{14}$} & 2010 & 2525 & 5025 & 10400 & 5375 & 1.07 & -2024 \\
& 2011 & 2558 & 5058 & 10880 & 5822 & 1.15 & -2448 \\
\hline
\end{tabular}

Note: EFI, $\mathrm{AFI}_{7}$, and $\mathrm{FFI}_{14}$ are referred to Every Furrow Irrigation, Fixed-Furrow Irrigation with 7-day intervals, and Fixed-Furrow Irrigation with 14-day intervals, respectively; Farming cost is calculated as summing of operating cost $\left(2500 \mathrm{LE} \mathrm{ha}^{-1}\right)$ and farming cost. 


\section{Conclusions}

Deficit irrigation treatments; i.e. fixed-furrow $\left(\mathrm{FFI}_{7}\right.$ with 7 days interval and $\mathrm{FFI}_{14}$ with 14 days interval) for irrigated maize were investigated in the Middle Nile Delta area of Egypt compared with every furrow irrigation (EFI, conventional method with 14 days interval). It can be concluded that the $\mathrm{FFI}_{7}$ treatment controlled stress irrigation without reduction risk in grain yield. Moreover, it increased the benefit-cost ratio (BCR), net return (NR), and saved irrigation water. The preference between $\mathrm{FFI}_{7}$ treatment and other treatments depends on the value of water with relation to crop returns. Therefore, it is recommended that if water was available with no high cost, and the excess water delivery to the field did not require additional expense, then the fixed-furrow irrigation with 7-days interval will practically be the best choice under the conditions of the studied area.

\section{References}

[1] El-Beltagy, A.T. \& Abo-Hadeed A.F., The main pillars of the National Program for maximizing the water-use efficiency in the old land. The Research and Development Council MOALR (In Arabic), 30 page bulletin, 2008.

[2] USDA-United States Department of Agriculture, Grain: World Markets and Trade. Foreign Agriculture Service, Circular series FG 09-11 Online. http://www.fas.usda.gov/psdonline/circulars/grain.pdf (accessed 9 October 2011).

[3] Mitchell, A.R., Shock, C.C. \& Perry, G.M., Alternating-furrow irrigation to minimize nitrate leaching to groundwater. Conference Proc 'Clean WaterClean Environment - 21st Century’, Kansas City, Missouri, ASAE, 1995.

[4] Raine, S.R. \& Bakker, D.M., Increased furrow irrigation efficiency through better design and management of cane fields. Proc Aust Soc Sugar Cane Tech, pp. 119-124, 1996.

[5] Mitchell, J.P., Shennan, C., Grattan, S.R. \& May, D.M., Tomato fruit yields and quality under water deficit and salinity. J Amer Soc Hort Sci, 116, pp. 215-221, 1991.

[6] Behboudian, M.H. \& Mills, T.M., Deficit irrigation in deciduous orchards. Hort Rev, 21, pp. 105-131, 1997.

[7] Slatni, A., Zayanib, K., Zairia, A., Yacoubia, S., Salvadorc, R. \& Playánc, E., Assessing alternate furrow strategies for potato at the Cherfech irrigation district of Tunisia. Biosystems Engineering, 108(2), pp. 154-163, 2011.

[8] Sepaskhah, A.R., \& Hosseini, S.N., Effects of alternate furrow irrigation and nitrogen application rates on yield and water- and nitrogen-use efficiency of winter wheat (Triticum aestivum L.). Plant Prod Sci, 11(2), pp. 250-259, 2008.

[9] Shayannejad, M. \& Moharrery, A., Effect of every-other furrow irrigation on water use efficiency, starch and protein contents of potato. Journal of Agriculture Science, 1(2), pp. 107-112, 2009. 
[10] Rafiee, M. \& Shakarami, G., Water use efficiency of corn as affected by every other furrow irrigation and planting density. World Applied Science Journal, 11(7), pp. 826-829, 2010.

[11] Nelson, D.J. \& Al-Kaisi, M.M., Agronomic and economic evaluation of various furrow irrigation strategies for corn production under limited water supply. Journal of Soil and Water Conservation, 66(2), pp. 114-120, 2011.

[12] Ryan, J., Estefan G., \& Rashid, A., Soil and Plant Analysis Laboratory Manual (2nd ed). The International Center for Agricultural Research in the Dry Areas (ICARDA), Aleppo, Syria and the National Agricultural Research Center (NARC), Islamabad, Pakistan, p. 172, 2001.

[13] Michael, A.M., Irrigation Theory and Practice. Vikas Publishing House PVT Limited, New Delhi, p. 520, 1978.

[14] Howell, T.A., Cuence, R.H., \& Solomon, K.H., Crop yield response. Management of Farm Irrigation Systems, ed. Hoffman GJ et al., ASAE St Joseph, MI, p. 312, 1990.

[15] Sampath, R.K. \& Nobe, K.C., Estimation of benefits from irrigation projects: Existing practice and an alternative model. Vikalpa, 8(4), p. 315, 1983.

[16] Li, A., Eneji, E., Duan, L., Inanaga, S. \& Li, Z., Saving irrigation water for winter wheat with phosphorus application in the north China plain. Journal of plant nutrition, 28, pp. 2001-2010, 2005.

[17] Ibrahim, S.A. \& Kandil, H., Growth, Yield and Chemical Constituents of Corn (Zea Maize L.) As Affected by Nitrogen and Phosphors Fertilization under Different Irrigation Intervals. J Appl Sci Res, 3, pp. 1112-1120, 2007.

[18] Sepaskhah, A.R. \& Ghasemi, M., Every-other-furrow irrigation with different intervals for grain sorghum. Pak J Biol Sci, 11(9), pp. 1234-1239, 2008

[19] Khan, M.H., Chattha, T.H. \& Saleem, N., Influence of Different Irrigation Intervals on Growth and Yield of Bell Pepper (Capsicum Annuum Grossum Group). J. Agric. Biolog. Sci., 1, pp. 125-128, 2005. 